\begin{tabular}{|c|c|c|c|c|c|c|}
\hline \multirow{4}{*}{ Impact Factor: } & ISRA (India) & $=3.117$ & SIS (USA) & $=0.912$ & ICV (Poland) & $=6.630$ \\
\hline & ISI (Dubai, UAE & $=0.829$ & РИНЦ (Russia) & $=0.156$ & PIF (India) & $=1.940$ \\
\hline & GIF (Australia) & $=0.564$ & ESJI $(\mathrm{KZ})$ & $=8.716$ & IBI (India) & $=4.260$ \\
\hline & JIF & $=1.500$ & SJIF (Morocco) & $=5.667$ & OAJI (USA) & $=0.350$ \\
\hline
\end{tabular}

\section{SOI: $\underline{1.1 / T A S}$ DOI: $\underline{10.15863 / T A S}$ International Scientific Journal Theoretical \& Applied Science}

p-ISSN: 2308-4944 (print) e-ISSN: 2409-0085 (online)

Year: 2019 Issue: $05 \quad$ Volume: 73

Published: $27.05 .2019 \quad \underline{\text { http://T-Science.org }}$

SECTION 19. Management. Marketing. Public administration.
QR - Issue

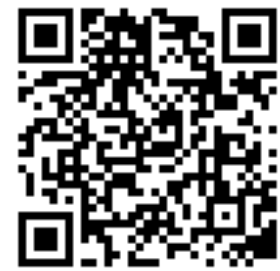

Vice-rector for international relations and educational work, Azerbaijan University of Cooperation, Baku, Azerbaijan Republic.

\title{
STRATEGIC ASPECTS OF THE MAIN OBJECTIVES OF THE STATE PROGRAM ON SOCIAL AND ECONOMIC DEVELOPMENT OF REGIONS IN AZERBAIJAN
} \begin{abstract}
development perspectives.
Language: English

\section{Introduction}

The issues of balancing of the state economic policy in terms of provision of priority guidelines subsequence and regions development in the country are of strategic meaning. Serious problems on dynamics and development efficiency of economics and society can occur without development of outlying regions and solving of social and economic problems in the regions. Furthermore ignoring of the regional problems can provoke undesirable tendency, for example, undesirable migration, immigration of resident population, depopulation of outlying villages, settlements, dissatisfaction of population in these regions, poverty increase, increase of unemployment and etc.
\end{abstract}

Abstract: Strategic aspects of the main objectives of the state program on social and economic development of the regions in Azerbaijan are researched in the article. With this aim there analyzed the essence of strategic aspects of regions development in different countries of the world. The approaches and mechanisms of Azerbaijan on realization of economic transitions in the regions are investigated. There are also analyzed three realized state programs on social and economic development of regions in Azerbaijan during 2004-2018. There is given the analysis of quantity of orders given by the President of Azerbaijan on development of regions and the number of participation in events on laying of foundation and opening of different objects in several regions of the country during 2004-2018. The poverty rate in the Republic of Azerbaijan during 2003-2018 and indicators of new workplaces opening in the regions during 2004-2018 are reviewed. There also revealed the main objectives and primary targets of the state program on social and economic development of the regions in Republic of Azerbaijan in 2019-2023. There are generalized the strategic aspects of the reviewed issues.

Key words: Azerbaijan, state programs, world experience in regions development, social and economic development of the regions, regions development issues, strategic aspects of regions development, regions

Citation: Guliyeva, A. E. (2019). Strategic aspects of the main objectives of the state program on social and economic development of regions in Azerbaijan. ISJ Theoretical \& Applied Science, 05 (73), 363-370.

Soi: http://s-o-i.org/1.1/TAS-05-73-53 Doi: crossef https://dx.doi.org/10.15863/TAS.2019.05.73.53

\section{Materials and Methods}

For this reason in many countries of the world the strategic emphasis is laid on social and economic development of the regions in the country [1]. Especially in developed countries the independent and more practical indicators for rehabilitation of depressed region are developed in order to adjust their development level to the nation-wide level or to put them into comparison with the analogic regions of the other countries [2]. There are developed special programs and strategies on effective use of labour power, natural resources of the regions, distribution of productive forces, development of specialized economic sectors, enterprises, infrastructure objects network, building of bridges, roads, water carriage and irritation systems. Moreover the social sphere, social infrastructure for provision of intellectual enrichment of regions population is developed with the aim of development of human capital assets for all intents and purposes. Today the modern regional policy fudges on restricted approach of targeting of the concrete regional problems and realization of 


\begin{tabular}{|c|c|c|c|c|c|c|}
\hline \multirow{4}{*}{ Impact Factor: } & ISRA (India) & $=3.117$ & SIS (USA) & $=0.912$ & ICV (Poland) & $=6.630$ \\
\hline & ISI (Dubai, UAI & $=0.829$ & РИНЦ (Russia & $=0.156$ & PIF (India) & $=1.940$ \\
\hline & GIF (Australia) & $=0.564$ & ESJI (KZ) & $=8.716$ & IBI (India) & $=4.260$ \\
\hline & JIF & $=1.500$ & SJIF (Morocce & $=5.667$ & OAJI (USA) & $=0.350$ \\
\hline
\end{tabular}

infrastructure projects [3]. For that purpose in many countries of the world there are reviewed the more creative approaches of stimulation of regional development by revealing the potential of economic growth and activity with the use of effective mechanisms of development of the enterprises and innovations, business and with the development of traditional employment sphere [4]. For example, in the USA in strategic policy the regional programs are most targeted at decrease of regional unemployment and opening of new workplaces, prevention of significant out migration. In Germany the active policy on differentiation of economic indicators level and regions development in comparison with more developed regions of the country is conducted. In Great Britain among the main targets of region development the enhancement of enterprise activity and decrease of immigration level in the regions are distinguished most of all [5]. In Spain the focused efforts on stimulation of regions development are carried out, the state support on decrease of unemployment and also rise of income of regions population is conducted. Besides, in many countries there are created specialized governmental authorities responsible for regulation and carrying out of regional policy of the country, regional investment and innovation projects, regions issues study and development of adequate measures on their solving [6]. Regional Development Agency functions in Great Britain, special Administration of economic development on support of depressive regions and the territories falling behind of general development in the state and in the country in a whole acts in the USA. In France the government actively subsidize and supports the regions of the country for increase of their development level and economic activity [7]. The special investment projects and grants are developed and carried out, tax holidays and remissions are provided for development of weak areas, depressive regions on balancing the social and economic development there [8]. The government should carry out the system approach to realization of the current economic potential of the region and provide the competitiveness increase, reveal of opportunities of economic activity, increase the investment attractiveness in the region. Besides, the government has to create more favorable conditions for attraction of local and foreign investors to the region, enhance the construction of public infrastructure [9]. It is critical to pay attention to the development of country enterprises and agricultural holdings, family and individual business, to stimulate the enterprise, to provide the accessibility of more cheap credit and financial resources for business development, development of consumer level, education and health care system [10]. It is necessary to decrease the disproportion and serious break in social and economic development of the region in comparison with the other regions of the country [10]. Stability of investment resources attractiveness to the region is of great importance, because without the financial provision the provision of essential changes in logjam of social and economic issues in the region, and first of all in the production field, seems to be impossible [11]. For modernization of production, development and innovation in different economic sectors, solution of logjam of social issues on regional level it is necessary to attract investment, and therefore respective investment climate [12]. Here we can agree with the author because in many countries of the world the low investment capital and high risks of entrepreneurship activity exist in the regions, there is lack of necessary infrastructure objects which are the main reasons and factors to reduce the local and foreign investment attraction to the region. Among the main problems of regional development the most standing out of them are the following: provision of diversification of production structure and economics of the region in a whole, lack of advanced technologies, machines and mechanisms, equipment for production enhancement in the regions [13]. Besides there is a vexed problem of weakness of the social and transport infrastructure [14]. It is necessary to solve the problem of unskillfulness of the most part of labor resources, lack of agricultural lands and fertilizers, and as we have mentioned before, insufficient financial solvency of the enterprise subjects and business in the regions.

The uncovering of regions problems by scientific basis and scientific provision of strategic planning of the social and economic region is of great importance. High level of differentiation of regions on the social and economic development level, changes in macroeconomic conditions leading to full-blown economic crisis demand the new approach to regulation of regional development directed to provision of wholeness and complexity of the processes of social and economic development on a nationwide scale and at the same allowing to consider their uniqueness in the framework of the separate region [15]. It is very important that in the regions there is provided the development of the system of regional resources and production forces management, the more progressive forms of management and business method were implemented. Balanced and improved system of management of the social and economic development of the region can sufficiently effect on developments in the region, can cause the consequent realization of strategic targets of accepted state programs in the region.

In realization of the main priority directions of the state program there is specially promoted the orders of the country President, who efficiently regulates the existing problems, including financial ones. In the Picture 1 there is shown the dynamics of the orders signed by President of Azerbaijan during 2004-2018. 


\begin{tabular}{llllll} 
& ISRA (India) $=\mathbf{3 . 1 1 7}$ & SIS (USA) & $=\mathbf{0 . 9 1 2}$ & ICV (Poland) & $=\mathbf{6 . 6 3 0}$ \\
Impact Factor: & ISI (Dubai, UAE) $=\mathbf{0 . 8 2 9}$ & PUHL (Russia) $=\mathbf{0 . 1 5 6}$ & PIF (India) & $=\mathbf{1 . 9 4 0}$ \\
& GIF (Australia) $=\mathbf{0 . 5 6 4}$ & ESJI (KZ) & $=\mathbf{8 . 7 1 6}$ & IBI (India) & $=\mathbf{4 . 2 6 0}$ \\
& JIF & $\mathbf{1 . 5 0 0}$ & SJIF (Morocco) $=\mathbf{5 . 6 6 7}$ & OAJI (USA) & $\mathbf{0 . 3 5 0}$ \\
\hline
\end{tabular}

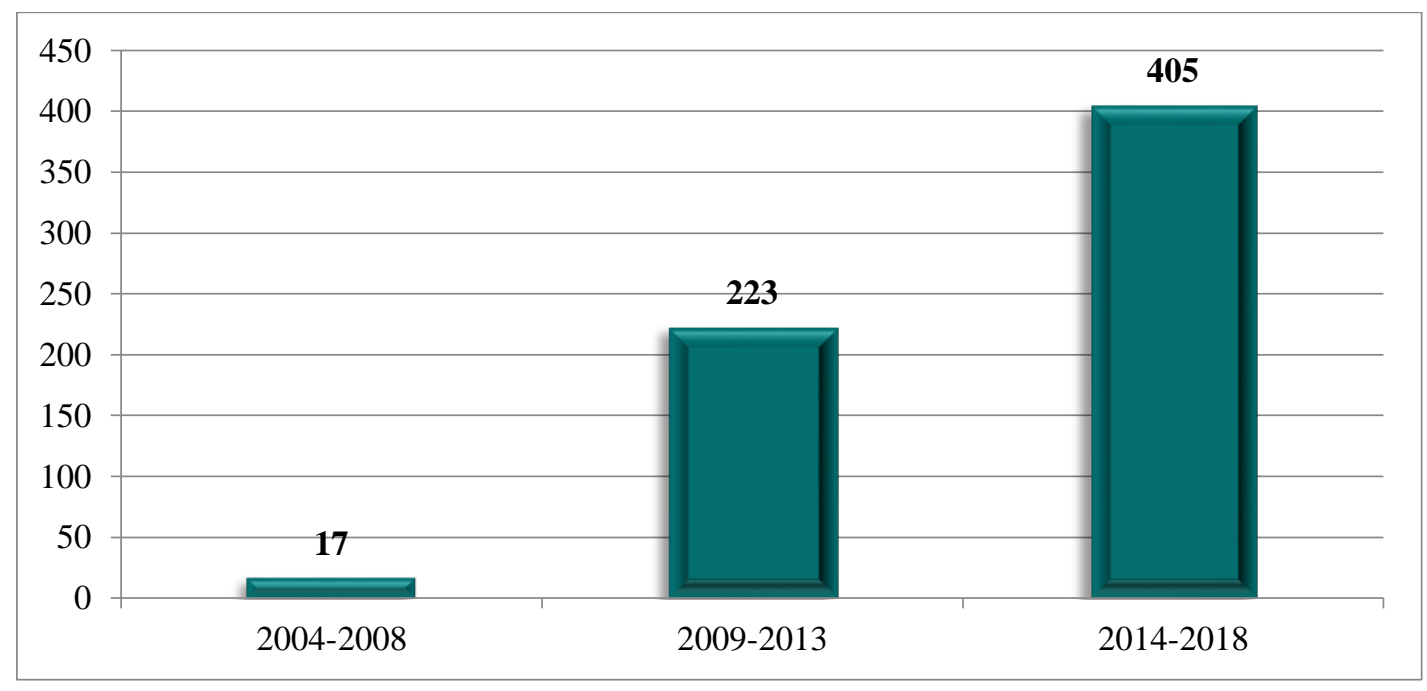

Picture 1. The number of orders by President of Azerbaijan on development of country regions during 20042018 (prepared by the author on the basis of materials of «State program on social and economic development of the regions in Azerbaijan Republic during 2019-2023, approved by the decree of the President of the country dated after 29.01.2019).

Besides the President of the country starting since 2004 till 2018 including participated 1821 times in events of laying the foundation and opening of different objects in the regions of Azerbaijan, and all this is shown in the Picture 2.

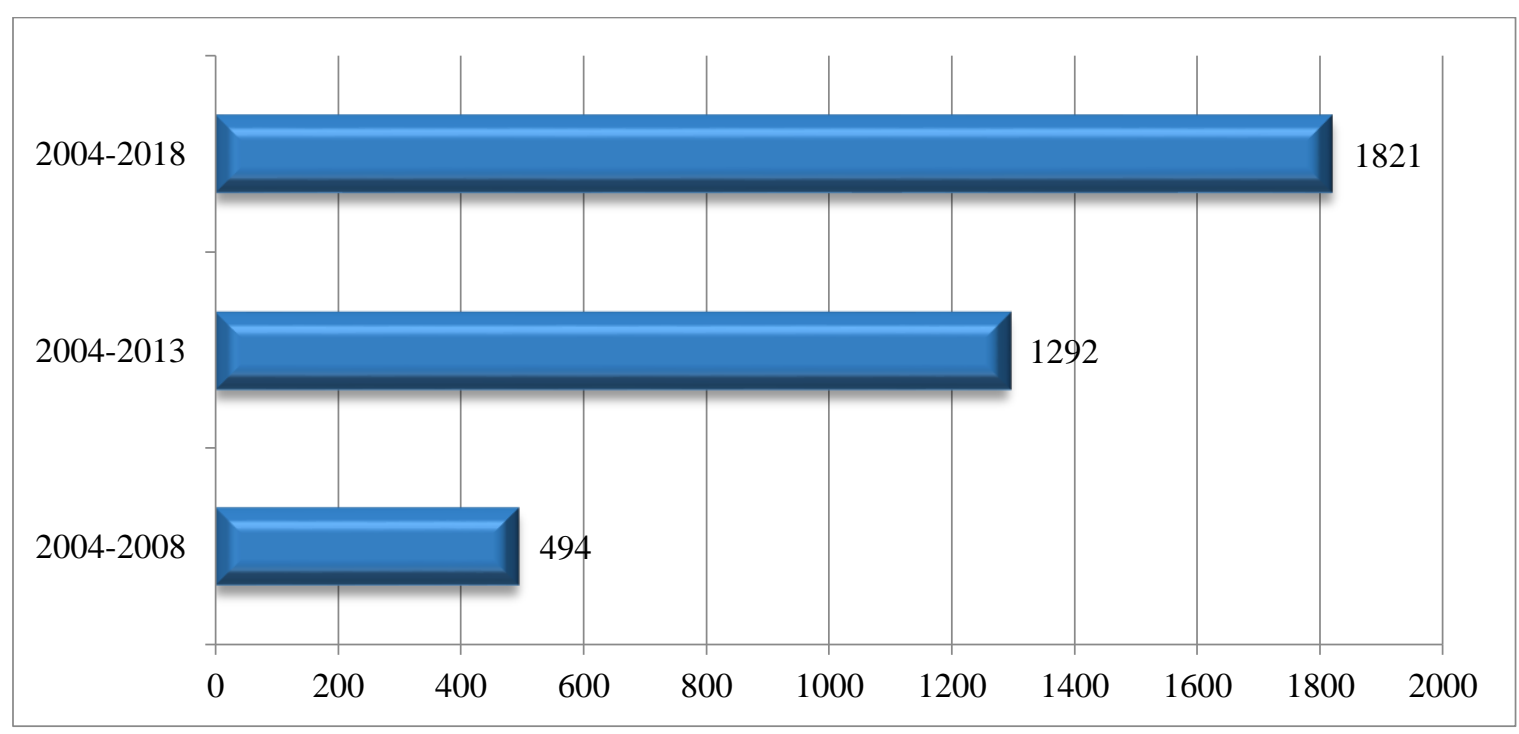

Picture 2. The number of participations of President of Azerbaijan in the events of laying foundation and opening of the objects in different regions of the country in the period of 2004-2018 (prepared by the author on the basis of materials of «State program on social and economic development of the regions in Azerbaijan Republic during 2019-2023, approved by the decree of the President of the country dated after 29.01.2019).

Balanced development boosted the concern of enterprise subjects, it made possible to reduce dependence of the country from the oil factor step-bystep. Thus in 2018 the concern of the private sector in GDP of the country composed $80 \%$, and more than $75 \%$ in employment. 950 thousand enterprise subjects function in the country and $66,6 \%$ falls to the share of regions. As we has mentioned before the poverty rate significantly decreased most of all because of opening of new workplaces and enterprises in the regions of the country, increase of their economic activity and productive use of labor resources. In the Picture 3 there is shown the poverty rate in Azerbaijan Republic during 2003-2018. 


\begin{tabular}{llllll} 
& ISRA (India) $=\mathbf{3 . 1 1 7}$ & SIS (USA) & $=\mathbf{0 . 9 1 2}$ & ICV (Poland) & $=\mathbf{6 . 6 3 0}$ \\
Impact Factor: & ISI (Dubai, UAE) $=\mathbf{0 . 8 2 9}$ & PUHL (Russia) $=\mathbf{0 . 1 5 6}$ & PIF (India) & $=\mathbf{1 . 9 4 0}$ \\
& GIF (Australia) $=\mathbf{0 . 5 6 4}$ & ESJI (KZ) & $=\mathbf{8 . 7 1 6}$ & IBI (India) & $=\mathbf{4 . 2 6 0}$ \\
& JIF & $\mathbf{1 . 5 0 0}$ & SJIF (Morocco) $=\mathbf{5 . 6 6 7}$ & OAJI (USA) & $\mathbf{0 . 3 5 0}$ \\
\hline
\end{tabular}

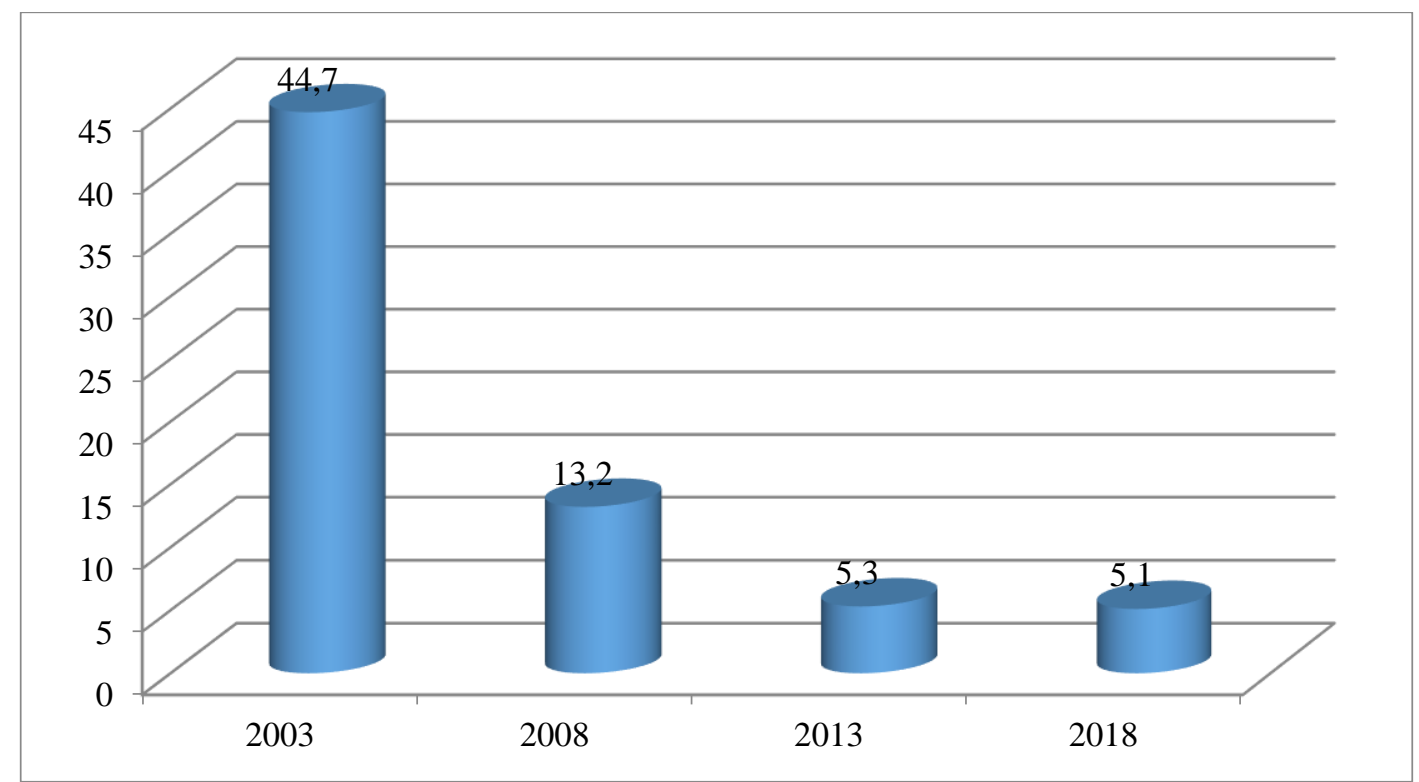

Picture 3. The poverty rate in Azerbaijan Republic during 2003-2018 (prepared by the author on the basis of materials of «State program on social and economic development of the regions in Azerbaijan Republic during 2019-2023, approved by the decree of the President of the country dated after 29.01.2019).

It is worth to mention that during 2004-2018 2 million of workplaces were opened in Azerbaijan and $75 \%$ of them falls to the share of country regions. In
Picture 4 you can see the indicators of workplaces opening by the regions of the country.

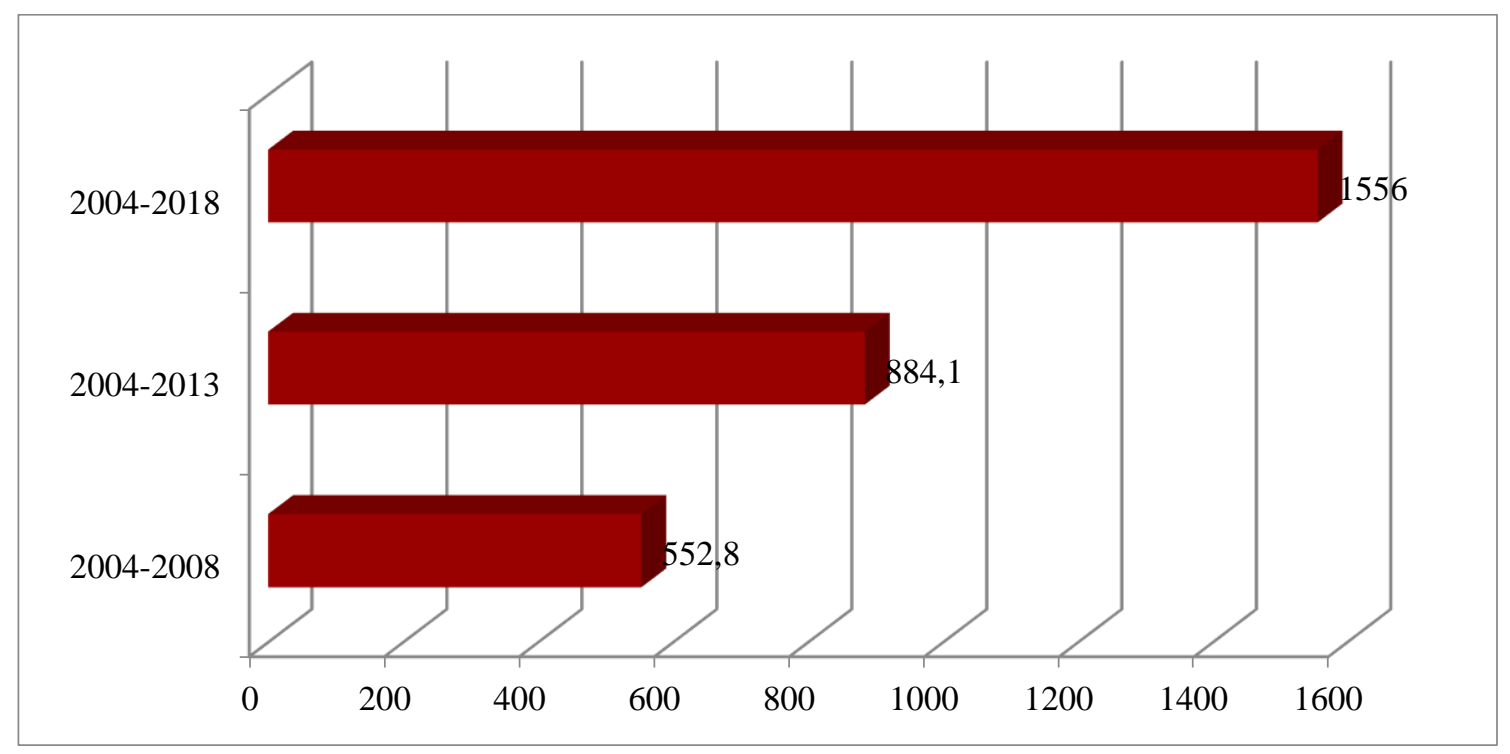

Picture 4. Indicators of opening of the workplaces in the regions of the country, thousand (prepared by the author on the basis of materials of «State program on social and economic development of the regions in Azerbaijan Republic during 2019-2023, approved by the decree of the President of the country dated after 29.01.2019).

It should be noted that nowadays Azerbaijan have set great and more strategic goals of modernization of the existing mechanism of economic development, and intends to decrease the dependence of economics of the country from the oil factor in a significant manner, and by this to provide the intensive development of non-oil sectors of country economics in the future perspective. To that end by the Decree of president of Azerbaijan Republic dated after December 6, 2016 there are confirmed the strategic roads maps on national economics and main economic sectors [16]. The main aims of this strategy is increase 


\begin{tabular}{|c|c|c|c|c|c|c|}
\hline \multirow{4}{*}{ Impact Factor: } & ISRA (India) & $=3.117$ & SIS (USA) & $=0.912$ & ICV (Poland) & $=6.630$ \\
\hline & ISI (Dubai, UAI & $=0.829$ & РИНЦ (Russia & $=0.156$ & PIF (India) & $=1.940$ \\
\hline & GIF (Australia) & $=0.564$ & ESJI (KZ) & $=8.716$ & IBI (India) & $=4.260$ \\
\hline & JIF & $=1.500$ & SJIF (Morocco & $=5.667$ & OAJI (USA) & $=0.350$ \\
\hline
\end{tabular}

of competitiveness and stability of national economics, improvement of its structure with the use of new technologies and provide innovation in a whole in the economics of the country. Besides, the strategic targets on enhancement and development of financial services in the country are determined in the nearest perspective [17]. All these created the more favourable conditions of acceleration of development of the country regions, which play the key role in development of the non-oil sector of economics, firs of all of the agriculture sector and agrarian sector in a whole, tourism sector and separate fields of industry (chemistry, oil-and-chemistry, metallurgy, and textile and food industry).

The strategic targets and priority directions of the functioning in the country regions, in provision of social and economic development of the regions during the next 5 years in a whole are reviewed separately, proved, developed and insisted. Thus, the 'State program on social and economic development of the regions in Azerbaijan Republic during 2019$2023^{\prime}$ is approved by the Decree of President of
Azerbaijan dated after January 29, 2019 [18]. During the opening words at the conference on January 29 , 2019 dedicated to the results of the fourth year of realization of the State program on social and economic development of the regions in 2014-2018 the President of Azerbaijan Ilham Aliyev noted that carried out economic and political reforms in the country, strengthening of our country let us save ourselves from the risk processes taking place in the world [19]. Further on the same conference the President of the country noted that the unsolved problems still exist. There are issue the solution of which was not possible or their turn has not come yet. We should not make a shift with executed work, we always have to look forward. We should know what is missing and where, and how to solve the issue [20]. In the Picture 5 there are given the main targets and aims of the state program on social and economic development of the regions in Azerbaijan Republic in 2019-2023. 


\begin{tabular}{|c|c|c|c|c|c|c|}
\hline \multirow{4}{*}{ Impact Factor: } & ISRA (India) & $=3.117$ & SIS (USA) & $=0.912$ & ICV (Poland) & $=6.630$ \\
\hline & ISI (Dubai, UAE & $=0.829$ & РИНЦ (Russia) & $=0.156$ & PIF (India) & $=1.940$ \\
\hline & GIF (Australia) & $=0.564$ & ESJI (KZ) & $=8.716$ & IBI (India) & $=4.260$ \\
\hline & JIF & $=1.500$ & SJIF (Morocco) & $=5.667$ & OAJI (USA) & $=0.350$ \\
\hline
\end{tabular}

The main targets and aims of the state program on social and economic development of the regions in Azerbaijan Republic during 2019-2023

Provision of improvement of the living conditions and income increase of the populations in the country regions
Provision of development of economic development potential, increase of economic activity and improvement of state support form for the development of local enterprises in the production and service sector
Provision of accessibility to the financial resources and credits on preferential terms for the enterprise subjects and agricultural holding, improvement of the legislative basis, economic and institution mechanisms in the processes of development of the regions

Provision of the effective buying system, logistics centre, storage holding and creation of the marketing network of the agrarian and agricultural products, especially for export
Increase of economic mechanisms and business forms competitiveness, provision of diversification of the country economics, creation of the more favorable conditions for formation of the competitive enterprises network

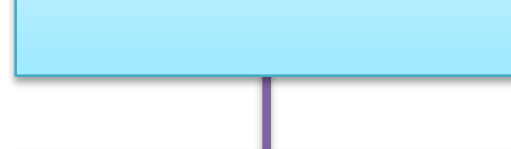

Increase of opportunity and potential of self-employment, decrease of unemployment level, development of social services and social infrastructure level, enhancement of social services structure in the regions

Provision of the significant development of the road and transport infrastructure in the villages, water supply system, and enhancement of the opportunities of the irritation system системы орошения

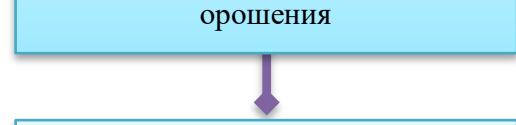

Development of the cooperation progression and agro-industrial integrations, governmental support of the development of the tourism services with the structure enhancement
Effective use of the natural and economic resources, and increase of investment innovation attractiveness of the regions

Increase of self-sufficiency level of the main types of food products and decrease of dependence form import, provision of enhancement of the list and increase of volume of the organic food products, first of all wheat

Provision of the stable development and descrease in the different of living standards in the central part, increase of the level of education and health care in the regions of the country

Provision of intensification of the enterprise development, especially of the subjects of small and medium business, family business
Strengthening of the governmental support, enhancement of the industrial sector on creation of additional cost nd inclusive character
Provision of accessibility of the insurance services in the regions of the country ad usage of multiplicative influence of the isurance to the economic development of the regions

Picture 5. The main targets and aims of the state program on social and economic development of the regions in Azerbaijan Republic in 2019-2023 (prepared by the author on the basis of materials of 'State program on social and economic development of the regions in Azerbaijan Republic in 2019-2023, approved by the Decree of the President of the country dated after 29.01.2019). 


\begin{tabular}{llllll} 
& ISRA (India) $=\mathbf{3 . 1 1 7}$ & SIS (USA) & $=\mathbf{0 . 9 1 2}$ & ICV (Poland) & $=\mathbf{6 . 6 3 0}$ \\
Impact Factor: & ISI (Dubai, UAE) $=\mathbf{0 . 8 2 9}$ & PUHL (Russia) $=\mathbf{0 . 1 5 6}$ & PIF (India) & $=\mathbf{1 . 9 4 0}$ \\
& GIF (Australia) $=\mathbf{0 . 5 6 4}$ & ESJI (KZ) & $=\mathbf{8 . 7 1 6}$ & IBI (India) & $=\mathbf{4 . 2 6 0}$ \\
& JIF & $\mathbf{1 . 5 0 0}$ & SJIF (Morocco) $=\mathbf{5 . 6 6 7}$ & OAJI (USA) & $\mathbf{0 . 3 5 0}$ \\
\hline
\end{tabular}

\section{Conclusion}

Thus, we have an opportunity to generalize the main forecasted results of realization of the State program on social and economic development of the regions in Azerbaijan Republic in 2019-2023 on the basis of the researched materials:

- The economics of the regions will be diversified on the account of formation of the modern enterprises of retreatment and enhancement of the production structure;

- There will be provided the potential of development in the regions of the country, especially in the villages, which will cause the effective use of the natural and economic resources of the regions;

- The development of the non-oil sectors of the economics in the country will be accelerated, and decrease of dependence of economics from the oil sector will be provided;

- The competitiveness of the regional economics and its sectors will increase significantly;

- High production growth and retreatment volume of the competitive agricultural products will be provided;
- There will be deepen the specialization on production and retreatment of the separate products types in the regions and the development level of the different sectors of agriculture and agrarian sector in a whole;

- The growth of export volume of the non-oil products including agrarian products will take place, which in a whole will increase the general potential of the export in the country;

- There will be strengthened the close collaboration and integration of the agrarian-industrial complex with the farming holdings and the other forms of holding in the regions;

- The growth of development of the additional cost amd productivity in all sectors of the agriculture is expected;

- The employment opportunities will increase, and there will be enhanced the list of events on decrease of unemployment level in the regions of the country;

- There will be provided the stable and balanced social nd economic development of the regions in a whole and etc.

\section{References:}

1. Podprugin, M. O. (2012). Ustoychivoye razvitiye regiona: ponyatiye, osnovnyye podkhody i factory. Rossiyskoye predprinimatel'stvo, Tom 13, №24, pp.214-221.

2. (2009). Regions Matter: Economic recovery, innovation and sustainable growth. (p.201). Paris: OECD.

3. Soderholm, P., \& Svahn, M. (2015). Mining, regional development and benefit-sharing in developed countries. Resources Policy, 45, pp. 78-91.

4. Mazol', O. (n.d.). Opyt zarubezhnykh stran v sfere razvitiya depressivnykh regionov. Retrieved 2019, from http://eng.beroc.by/webroot/delivery/files/PP62. pdf

5. Artobolevskiy, S. S. (1992). Regional'noye razvitiye $v$ Velikobritanii. (p.165). Moscow: Institut geografii RAN.

6. (2009). Governing Regional Development Policy: the use of performance indicators. (p.198). Paris: OECD.

7. (2009). OECD Reviews of Regional Innovation. Globalisation and Regional Economies: Can
OECD regions compete in global industries? (p.246). Paris: OECD.

8. (2010). Regional Development Policies in OECD Countries. (p.388). Paris: OECD.

9. Balanina, G. F. (2009). Strategiya razvitiya depressivnogo regiona / Pod red. d-ra ekon. nauk. S. V.Paramonova (Eds.). (p.344). Kyzyl: TuviKOPR SO RAN.

10. Bestayeva, L. I. (2015). Tendentsii disproportsiy sotsial'no-ekonomicheskogo razvitiya regionov. Fundamental'nyye issledovaniya, №10-3, pp.564-569.

11. (2014). Regional'naya ekonomika. (p.583). Moskva: Izdatel'stvo Yurayt.

12. Plisetskiy, Y. L. (2012). Territorial'nyye razlichiya rossiyskoy ekonomiki i obshchestva. Regional'naya ekonomika: teoriya $i$ praktika. Moskva, № 24, pp. 2-12.

13. Kroshilin, S. V., Leonova, Z. K., Medvedeva, Y. I., \& Ivanina, V. M. (n.d.). Tipologicheskiye osobennosti ekonomicheskogo razvitiya regionov Rossii $v$ usloviyakh razvitiya nepreryvnogo obrazovaniya. Retrieved 2019, from http://esc.isert-ran.ru/article/1724 


\begin{tabular}{llllll} 
& ISRA (India) $=\mathbf{3 . 1 1 7}$ & SIS (USA) & $=\mathbf{0 . 9 1 2}$ & ICV (Poland) & $=\mathbf{6 . 6 3 0}$ \\
Impact Factor: & ISI (Dubai, UAE) $=\mathbf{0 . 8 2 9}$ & PUHL (Russia) $=\mathbf{0 . 1 5 6}$ & PIF (India) & $=\mathbf{1 . 9 4 0}$ \\
& GIF (Australia) $=\mathbf{0 . 5 6 4}$ & ESJI (KZ) & $=\mathbf{8 . 7 1 6}$ & IBI (India) & $=\mathbf{4 . 2 6 0}$ \\
& JIF & $\mathbf{1 . 5 0 0}$ & SJIF (Morocco) $=\mathbf{5 . 6 6 7}$ & OAJI (USA) & $\mathbf{0 . 3 5 0}$ \\
\hline
\end{tabular}

14. Rokicki, B., \& Stępniak, M. (2018). Major transport infrastructure investment and regional economic development - An accessibility-based approach. Journal of Transport Geography, 72, pp.36-49.

15. Morozov, S. I., \& Smirnov, Y. B. (2011). Problemy nauchnogo obespecheniya strategicheskogo planirovaniya sotsial'noekonomicheskogo razvitiya regiona. Problemy sovremennoy ekonomiki, №3 (39). http://www.economy.ru/art.phd?nArtld=3722

16. (2016). Strategicheskiye dorozhnyye karty po natsional'noy ekonomike i osnovnym sektoram ekonomiki. Utverzhdeno Ukazom Prezidenta Azerbaydzhankoy Respubliki ot 6 dekabrya 2016 goda.

17. (2016). Strategicheskiye dorozhnyye karty o razvitii finansovykh uslug $v$ Azerbaydzhanskoy Respublike. Utverzhdeno Ukazom Prezidenta Azerbaydzhankoy Respubliki ot 6 dekabrya 2016 goda.
18. (2019). Ukaz Prezidenta Azerbaydzhanskoy Respubliki ob utverzhdenii "Gosudarstvennoy programmy sotsial'no-ekonomicheskogo razvitiya regionov Azerbaydzhanskoy Respubliki v 2019-2023 godakh». Baku, Retrieved Jan. 29, 2019 ,

from https://ru.president.az/articles/31697/print

19. (2019). Vstupitel'naya rech' Il'khama Aliyeva na konferentsii, posvyashchennoy itogam chetvertogo goda realizatsii Gosudarstvennoy programmy sotsial'no-ekonomicheskogo razvitiya regionov $v$ 2014-2018 godakh. Retrieved Jan. 29, 2019, from https://ru.president.az/articles/31711/print

20. (2019). Zaklyuchitel'naya rech' Il'khama Aliyeva na konferentsii, posvyashchennoy itogam chetvertogo goda realizatsii Gosudarstvennoy programmy sotsial'no-ekonomicheskogo razvitiya regionov $v$ 2014-2018 godakh. Retrieved Jan. 29, 2019, from https://ru.president.az/articles/31713/print 